\title{
Investigation of the Effects of Football on Life Skills of Individuals
}

\author{
Kemal Kurak ${ }^{1, *}$, Mahmut Açak ${ }^{2}$ \\ ${ }^{1}$ MKE Ankaragücü, Turkey \\ ${ }^{2}$ Faculty of Sport Sciences, Inonu Universitesi, Turkey
}

Copyright $\odot 2019$ by authors, all rights reserved. Authors agree that this article remains permanently open access under the terms of the Creative Commons Attribution License 4.0 International License

\begin{abstract}
This study aims to investigate how football, which is the most popular sport today, affects the life skills of individuals who participate in football activities. The participants in the study were between 12 to 17 years old and those who participated in training for at least two years were chosen. As the measurement tool, the unique form Life Skills Scale for Sport was used with the aim of evaluating the life skills gained through sports. For two-sample comparisons, Mann Whitney U test was used; while for multiple-sample comparisons, Kruskal Wallis $\mathrm{H}$ test was utilized. In the multiple sample comparisons, Mann Whitney U test, which is used for non-parametric data, was used to determine the source of the difference. In the study, the level of significance was regarded as $p<0.05$. Depending on the variables of age, the period of doing sports and playing continuously in a football team of the study group, it was determined that the study group developed skills for time management, communication, leadership, teamwork, social skills and goal setting, which are subscales of the life skills for sport. Emotional skills were determined to be not statistically significant.
\end{abstract}

Keywords Sport, Life Skills, Football, Social Skills

\section{Introduction}

The main subject of life skills covers socializing skills, which are thought to be the belief in one's own abilities and being included in the society, at a level of being able to show a positive reflection. The fact that gaining life skills during childhood and adolescence constitutes preparation for adulthood also renders this subject more important. To succeed in our competitive and ever-changing global economy young people must develop an abundance of life skills. Such life skills are defined as the skills required dealing with the demands and challenges of everyday life. Research suggests that young people develop their life skills through extracurricular activities such as music, drama, and sport, sport has the greatest number of positive effects of any extracurricular activity. In particular, it has been proposed that the interactive, emotional, and social aspects of sport make it a promising setting for young peoples' development.

The ability of young people to meet their own needs when faced with both physical and psychological situations during the school period can only be made possible by developing life skills. In terms of developing social skills, young people comprise a special group that should especially be emphasized. This is because the development of life skills to meet the needs of young people covers achieving basic duties regarding the development process of humans. In fact, in modern societies, the questions of what are important life skills to ensure young people live and develop in a healthy and quality way and how they can be developed are discussed. At this point, it is stated that abilities necessary to cope with life should be included in education programs as inseparable elements. Life skills ensure that young people manage their lives in a successful way and adapt to different life events. Therefore, it is imperative for young people to develop various life skills in order to be successful by adapting to competitive and continuously changing life conditions brought by the age. Because life skills are indirectly related with situations such as academic success [1], sports and exercise performance [2], general health [3], psychological well-being [4], workplace efficiency and success [5], they play a determinant role in individuals' lives. Additionally, if life skills, which enable individuals to deal with the problems of transitioning into adolescence and its problems in a more efficient way, are transferred to various fields of life and used, they can help young people to develop in a healthy way and become successful, for example, by keeping them away from harmful behaviors such as using alcohol and drugs [6]. Therefore, sports activities, which are the most popular leisure-time activity for young people, can create an ideal environment for 
developing life skills. This is because studies report that young people can develop life skills in an easier way through extracurricular activities such as music, drama and sports [7] and that sports, as an extracurricular activity, contribute positively to the life skills of children and adolescents, especially by creating a positive environment in terms of emotional and social ways of young people and their interactions with each other. Furthermore, it is known that life skills developed through sports play a key role in young people's positive development in mental, social and physical aspects. Thus, it is rather significant to teach life skills to young people in a conscious way in order for young people to develop a positive attitude towards life and adapt in an easier way.

Sport is an action science that provides physical, spiritual and social development of individuals .Individuals should have the opportunity to do sports, improve the body form and reach the level of sportive performance appropriate to their abilities. Special environments should be prepared to ensure the basic development of their personalities through sports programs appropriate to the needs of all individuals who make up the community, including children in pre-school age .The contribution of sport to life skills is explained below.

Social skills are a matter of concern in relation to the child's social competence. It can be defined as the individual's performance in a given social requirement such as qualification, building friendship, joining others, and agreement with others.Accordingly, social competence; It is a total judgment that can be determined by an adult such as a teacher or parent. Social skills are self -directed paths that lead an individual to fulfill social requirements .

Emotional development is the child's ability to express himself, to control his emotions, to be in harmony and harmony with himself and his environment. Studies on the emotional characteristics of children have shown that emotional development occurs as a result of both maturation and learning, and none of them are effective .

According to sociologists, leadership is the personal authority used to influence social groups. Provides the existence of leadership; The characteristics of the personal authority are the qualities such as forward vision, various character traits, certainty, courage, accuracy, intelligence, credibility. Under certain circumstances, the individual or the group may have the meaning of influencing the activities of a leader in his/ her environment and the direction-making process in order to realize their goals .

Time management is an effort to use time efficiently, which is an important resource for achieving goals and goals. What is involved in time management is planning what can be done at the present time. Time management is not to do the wrong jobs fast. The goal is to do the right things in a short time. Time management is a technique of improving personal performance which is important in terms of achieving the objectives, controlling the work done and raising the individual's motivation.

Communication skills include researching, investigating and integrating the person, the possible perspectives and definitions related to the incident he / she is facing. Someone gained this skill, a warning against him, in the face of criticism or complaint, rather than a single angle would be capable of giving meaning many ways.Communication skills are the most forgotten skills that can be taught and learned, but not exercised on the subject .The bodily awareness that can be provided by sportive activities can be effective in the conscious use of the body language. Obtaining the habit of exercising from an early age is one of the non-verbal messages that are important in effective communication and should be considered .

The aim of the study: findings were obtained that sports develop many life skills such as teamwork, goal setting, initiative, respecting others, time management, cognitive skills, emotional skills, communication skills, social skills, leadership, problem-solving and decision making. Within this scope, the study aims to investigate how participating in football activities, which is one of the most popular sports today, affect the life skills of individuals.

\section{Method}

\subsection{Population and Sampling/Study Group}

The population of the study consists of football players in the youth setups of football teams active in the Turkish Super League during the 2017-2018 football season. As the participation criteria in the study, it was required to participate voluntarily in the study and being participated in training in football teams. The participants' variables of age and the period of doing sports were evaluated.

\subsection{Measurements and Tests in the Study (Data Collection)}

The questionnaire form consisting of a personal information form and life skills scale for sports was conducted with the participants and the participants were asked to answers these items sincerely.

As the measurement tool, the unique form of Life Skills Scale for Sport (LSSS), which was developed by Cronin and Allen in 2017 as a 5-point Likert type scale, was adopted in order to evaluate life skills developed through sports [8]. The scale can be conducted with high school students and university students, who are up to 21 years old. The scale, whose Turkish validity and reliability study was conducted by [9], consists of 7 subscales, which are teamwork, goal setting, time management, emotional skills, communication, social skills and leadership, and 31 items. Each item in the scale is scored in the 5-point Likert scale as not at all, a little, some, a lot and very much. There is no item in the scale to score reversely. 


\subsection{Data Analysis}

In order to analyze the data obtained as a result of the study, a statistics package software (SPSS version 21) was used. Prior to statistical analyses, "Shapiro-Wilks and Kolmogorov-Smirnov" normality analyses were conducted in order to determine whether the data had a normal distribution and whether it was homogenous. As a result of the tests, it was observed that the data did not have a normal distribution and non-parametric tests were used in the analyses. For two-sample comparisons, Mann Whitney U test was used while for multiple-sample comparisons, Kruskal Wallis $\mathrm{H}$ test was used. In order to find the source of the difference in multiple-sample comparisons, Mann Whitney $U$ test, which is used for non-parametric data, was used. In the study, the level of significance was regarded as $\mathrm{p}<0.05$.

\section{Results}

The data obtained from the study group were subjected to necessary and appropriate analyses and presented in the tables below.

According to Table 1, the study group included $29.4 \%$ of participants aged between 10 and $12,38.2 \%$ aged between 13 and 15 and $32.4 \%$ aged between $16-17$ years old.
Table 1. Age distribution of the study group

\begin{tabular}{|l|c|c|}
\hline \multicolumn{1}{|c|}{ Age } & n & \% \\
\hline $10-12$ years old & 120 & 29,4 \\
\hline $13-15$ years old & 156 & 38,2 \\
\hline $16-17$ years old & 132 & 32,4 \\
\hline Total & 408 & 100,0 \\
\hline
\end{tabular}

According to Table 2, the study group consisted of $31.9 \%$ of participants doing sports for $2-3$ years, $25.2 \%$ doing sports for $4-5$ years, $21.3 \%$ doing sports for $6-7$ years and $21.6 \%$ doing sports for 8 years or more.

Table 2. Period of doing sports distribution of the study group

\begin{tabular}{|l|c|c|}
\hline \multicolumn{1}{|c|}{ Period of doing sports } & n & \% \\
\hline 2-3 years & 130 & 31,9 \\
\hline 4-5 years & 103 & 25,2 \\
\hline 6-7 years & 87 & 21,3 \\
\hline 8 years or more & 88 & 21,6 \\
\hline Total & 408 & 100,0 \\
\hline
\end{tabular}

According to Table 3, depending on the variable of age, it was determined that the study group demonstrated statistically significant differences in all of the subscales of the life skills scale for sport, except for the subscale of emotional skills $(\mathrm{p}<0.05)$.

Table 3. Analysis results of the study group according to the variable of age

\begin{tabular}{|c|c|c|c|c|c|c|c|c|}
\hline \multicolumn{3}{|c|}{ Age } & $\mathbf{N}$ & Mean & SD & $X^{2}$ & $\mathbf{p}$ & Difference $U$ test \\
\hline \multirow{3}{*}{ Time Management } & 1 & $10-12$ years old & 80 & 14,02 & 2,06 & \multirow{3}{*}{23,273} & \multirow{3}{*}{, $000^{*}$} & \multirow{3}{*}{$\begin{array}{l}3>2 \\
3>1 \\
2>1\end{array}$} \\
\hline & 2 & 13-15 years old & 196 & 16,79 & 3,12 & & & \\
\hline & 3 & 16-17 years old & 232 & 19,85 & 3,35 & & & \\
\hline \multirow{3}{*}{ Communication } & 1 & $10-12$ years old & 80 & 15,15 & 2,55 & \multirow{3}{*}{10,257} & \multirow{3}{*}{, $022 *$} & \multirow{3}{*}{$3>1,2$} \\
\hline & 2 & $13-15$ years old & 196 & 15,07 & 3,02 & & & \\
\hline & 3 & 16-17 years old & 232 & 18,02 & 3,33 & & & \\
\hline \multirow{3}{*}{ Leadership } & 1 & 10-12 years old & 80 & 16,46 & 3,22 & \multirow{3}{*}{20,791} & \multirow{3}{*}{, $002 *$} & \multirow{3}{*}{$3>1,2$} \\
\hline & 2 & $13-15$ years old & 196 & 16,71 & 3,99 & & & \\
\hline & 3 & $16-17$ years old & 232 & 18,41 & 4,00 & & & \\
\hline \multirow{3}{*}{ Teamwork } & 1 & $10-12$ years old & 80 & 14,11 & 4,51 & \multirow{3}{*}{20,128} & \multirow{3}{*}{, $000 *$} & \multirow{3}{*}{$\begin{aligned} & 3>1,2 \\
& 2>1\end{aligned}$} \\
\hline & 2 & 13-15 years old & 196 & 20,41 & 4,80 & & & \\
\hline & 3 & $16-17$ years old & 232 & 22,65 & 4,70 & & & \\
\hline \multirow{3}{*}{ Social Skills } & 1 & 10-12 years old & 80 & 14,12 & 3,35 & \multirow{3}{*}{16,312} & \multirow{3}{*}{,003* } & \multirow{3}{*}{$3>1,2$} \\
\hline & 2 & $13-15$ years old & 196 & 15,14 & 3,21 & & & \\
\hline & 3 & 16-17 years old & 232 & 18,93 & 3,45 & & & \\
\hline \multirow{3}{*}{ Emotional Skills } & 1 & 10-12 years old & 80 & 14,07 & 3,16 & \multirow{3}{*}{13,375} & \multirow{3}{*}{$-1,411^{*}$} & \multirow{3}{*}{, 312} \\
\hline & 2 & 13-15 years old & 196 & 14,41 & 3,59 & & & \\
\hline & 3 & 16-17 years old & 232 & 14,73 & 3,71 & & & \\
\hline \multirow{3}{*}{ Goal Setting } & 1 & $10-12$ years old & 80 & 14,80 & 2,95 & \multirow{3}{*}{16,100} & \multirow{3}{*}{, $031 *$} & \multirow{3}{*}{$3>1,2$} \\
\hline & 2 & 13-15 years old & 196 & 14,83 & 3,16 & & & \\
\hline & 3 & $16-17$ years old & 232 & 17,04 & 3,42 & & & \\
\hline
\end{tabular}


According to Table 4, depending on the variable of the period of doing sports, it was determined that the study group demonstrated statistically significant differences in all of the subscales of the life skills scale for sport, except for the subscales of emotional skills and goal setting $(\mathrm{p}<0.05)$.

Table 4. Analysis results of the study group according to the variable of the period of doing sports

\begin{tabular}{|c|c|c|c|c|c|c|c|c|}
\hline \multicolumn{3}{|c|}{ Period of Doing Sports } & $\mathbf{N}$ & Mean & SD & $\mathbf{X}^{2}$ & $\mathbf{p}$ & Difference $U$ test \\
\hline \multirow{4}{*}{ Time Management } & 1 & $2-3$ years & 130 & 14,16 & 3,65 & \multirow{4}{*}{25,173} & \multirow{4}{*}{, $000^{*}$} & \multirow{4}{*}{$4>1,2,3$} \\
\hline & 2 & $4-5$ years & 103 & 14,82 & 3,17 & & & \\
\hline & 3 & 6-7 years & 87 & 14,22 & 3,25 & & & \\
\hline & 4 & 8 years & 88 & 16,28 & 3,60 & & & \\
\hline \multirow{4}{*}{ Communication } & 1 & $2-3$ years & 130 & 14,06 & 3,12 & \multirow{4}{*}{16,373} & \multirow{4}{*}{, $001 *$} & \multirow{4}{*}{$\begin{array}{c}3>1,2 \\
4>1,2,3\end{array}$} \\
\hline & 2 & $4-5$ years & 103 & 14,74 & 3,85 & & & \\
\hline & 3 & 6-7 years & 87 & 15,08 & 3,22 & & & \\
\hline & 4 & 8 years & 88 & 18,68 & 3,53 & & & \\
\hline \multirow{4}{*}{ Leadership } & 1 & $2-3$ years & 130 & 16,26 & 3,26 & \multirow{4}{*}{23,639} & \multirow{4}{*}{, $000 *$} & \multirow{4}{*}{$4>1,2,3$} \\
\hline & 2 & $4-5$ years & 103 & 16,66 & 3,89 & & & \\
\hline & 3 & $6-7$ years & 87 & 16,86 & 4,02 & & & \\
\hline & 4 & 8 years & 88 & 20,95 & 4,48 & & & \\
\hline \multirow{4}{*}{ Teamwork } & 1 & $2-3$ years & 130 & 20,18 & 4,90 & \multirow{4}{*}{18,230} & \multirow{4}{*}{, $002 *$} & \multirow{4}{*}{$\begin{array}{c}2>1 \\
3>1,2 \\
4>1,2,3\end{array}$} \\
\hline & 2 & $4-5$ years & 103 & 22,32 & 4,60 & & & \\
\hline & 3 & 6-7 years & 87 & 26,62 & 4,74 & & & \\
\hline & 4 & 8 years & 88 & 28,20 & 4,94 & & & \\
\hline \multirow{4}{*}{ Social Skills } & 1 & $2-3$ years & 130 & 14,42 & 2,21 & \multirow{4}{*}{13,173} & \multirow{4}{*}{, $004 *$} & \multirow{4}{*}{$\begin{array}{c}3>1,2 \\
4>1,2,3\end{array}$} \\
\hline & 2 & $4-5$ years & 103 & 14,39 & 3,82 & & & \\
\hline & 3 & $6-7$ years & 87 & 16,98 & 3,45 & & & \\
\hline & 4 & 8 years & 88 & 18,64 & 3,26 & & & \\
\hline \multirow{4}{*}{ Emotional Skills } & 1 & $2-3$ years & 130 & 14,56 & 3,51 & \multirow{4}{*}{29,339} & \multirow{4}{*}{2,746} & \multirow{4}{*}{, 526} \\
\hline & 2 & $4-5$ years & 103 & 14,83 & 3,60 & & & \\
\hline & 3 & 6-7 years & 87 & 14,78 & 3,47 & & & \\
\hline & 4 & 8 years & 88 & 14,24 & 4,03 & & & \\
\hline \multirow{4}{*}{ Goal Setting } & 1 & 2-3 years & 130 & 16,40 & 3,37 & \multirow{4}{*}{3,360} & \multirow{4}{*}{3,586} & \multirow{4}{*}{,268 } \\
\hline & 2 & $4-5$ years & 103 & 16,06 & 3,15 & & & \\
\hline & 3 & $6-7$ years & 87 & 15,88 & 3,52 & & & \\
\hline & 4 & 8 years & 88 & 15,58 & 3,87 & & & \\
\hline
\end{tabular}

$* \mathrm{p}<0.05$

Table 5. Analysis results of the study group according to the variable of the period of playing continuously in a football team

\begin{tabular}{|c|c|c|c|c|c|c|}
\hline \multicolumn{2}{|c|}{ Do you play in the school team? } & $\mathbf{N}$ & Mean & SD & $\mathbf{Z}$ & $\mathbf{p}$ \\
\hline \multirow{2}{*}{ Time Management } & Yes & 194 & 14,69 & 2,36 & \multirow{2}{*}{$-5,158$} & \multirow{2}{*}{, $000^{*}$} \\
\hline & No & 214 & 18,15 & 3,51 & & \\
\hline \multirow{2}{*}{ Communication } & Yes & 194 & 15,22 & 3,52 & \multirow{2}{*}{$-3,815$} & \multirow{2}{*}{, $003^{*}$} \\
\hline & No & 214 & 18,35 & 3,25 & & \\
\hline \multirow{2}{*}{ Leadership } & Yes & 194 & 16,32 & 3,52 & \multirow{2}{*}{$-5,447$} & \multirow{2}{*}{, $000^{*}$} \\
\hline & No & 214 & 19,84 & 4,95 & & \\
\hline \multirow{2}{*}{ Teamwork } & Yes & 194 & 21,18 & 4,32 & \multirow{2}{*}{$-7,912$} & \multirow{2}{*}{, $000^{*}$} \\
\hline & No & 214 & 24,48 & 4,28 & & \\
\hline \multirow{2}{*}{ Social Skills } & Yes & 194 & 14,74 & 2,19 & \multirow{2}{*}{$-3,901$} & \multirow{2}{*}{, $000^{*}$} \\
\hline & No & 214 & 16,48 & 3,75 & & \\
\hline \multirow{2}{*}{ Emotional Skills } & Yes & 194 & 15,54 & 3,18 & \multirow{2}{*}{$-8,624$} & \multirow{2}{*}{, $349 *$} \\
\hline & No & 214 & 15,73 & 3,22 & & \\
\hline \multirow{2}{*}{ Goal Setting } & Yes & 194 & 15,73 & 2,15 & \multirow{2}{*}{$-5,624$} & \multirow{2}{*}{, $000^{*}$} \\
\hline & No & 214 & 17,42 & 3,24 & & \\
\hline
\end{tabular}


According to Table 5, depending on the variable of playing continuously in a football team, it was determined that the study group demonstrated statistically significant differences in all of the subscales of the life skills scale for sport, except for the subscale of emotional skills $(\mathrm{p}<0.05)$.

\section{Discussion}

In this study, the study group consists of 408 athletes playing football in youth setups in football teams active in the Turkish Super League during the 2017-2018 football season.

According to Table 3, depending on the variable of age, it was determined that the study group demonstrated statistically significant differences in all of the subscales of the life skills scale for sport, except for the subscale of emotional skills. As the age of football players doing sports increases, it was determined that they designed time management in a better way, improved their leadership qualities, developed their teamwork spirit, improved their social skills and developed their goal setting skills. Between the ages of the study group, it was determined that there was no difference between the emotional skills. Korkut (2011) reported that gaining the behavior of exercise starting from young ages was determined to be important in effective communication [10]. Özerkan (2005) stated that individuals who do sports had higher tendencies to establish communication compared to individuals who do not do sports [11].

According to Table 4, depending on the variable of the period of doing sports, it was determined that the study group demonstrated statistically significant differences in the subscales of time management, communication, leadership, teamwork and social skills. Açak and Karademir (2011) determined that according to the variable of participating in sports activities, statistically significant differences were determined between the mean scores of self-respect on behalf of those who participate in sports. In the variable of the period of doing sports, no statistically significant difference was determined in the subscales of emotional skills and goal setting [12].

According to Table 5, depending on the variable of playing continuously in a football team, it was determined that the study group demonstrated statistically significant differences in the subscales of time management, communication, communication, leadership, teamwork, social skills and goal setting. In emotional skills, no statistically significant difference was determined. In the literature review, many findings were observed regarding the fact that sports developed many life skills such as teamwork [13], time management [14], cognitive skills [15], emotional skills [16], communication skills [17], social skills [18] and leadership [19], which supports the findings of this study. It is believed that this subject should be further clarified by studying with more subjects and various branches of sports.

As a result, with the years of sports, we can start with early sports, the frequency of sports, playing in school or club teams, working with different coaches, and affecting young people's life skills. Therefore, it is recommended that young people start sports at an early age in order to improve their life skills.

\section{REFERENCES}

[1] Humphrey, N., Kalambouka, A., Wigelsworth, M., Lendrum, A., Deighton, J., \& Wolpert, M. (2011). Measures of social and emotional skills for children and young people: A systematic review. Educational and Psychological Measurement, 71(4), 617-637.

[2] Burton, D., Naylor, S., ve Holliday, B. (2001). Goal setting in sport: Investigating the goal effectiveness paradox. In R. Singer, H. Hausenblas, \& C. Janelle (Eds.), Handbook of sport psychology, pp. 497-528.

[3] Claessens, B. J., VanEerde, W., Rutte, C. G., ve Roe, R. A. (2007). A review of time management literature. Personnel Review, 36(2), 255-276.

[4] Judge, T. A., Bono, J. E., Erez, A., ve Locke, E. A. (2005). Core self-evaluations and job and life satisfaction: The role of self-concordance and goal attainment. The Journal of Applied Psychology, 90(2), 257-268.

[5] Rubin, R.B., ve Morreale, S.P. (1996). Setting expectations for speech communication and listening. In E. A. Jones (Ed.), Preparing competent college graduates: Setting new and higher expectations for student learning. New Directions for Higher Education, 96, 19-29.

[6] Botvin, G. J., Griffin, K. W. (2004). Life skills training: Empirical findings and future directions. The Journal of Primary Prevention. 25: 211-232.

[7] Larson, R.W. (2000). Toward a psychology of positive youth development. American Psychologist, 55(1), 170-183.

[8] Cronin, L. D., ve Allen, J. (2017). Development and initial validation of the Life Skills Scale for Sport. Psychology of Sport and Exercise. 28, 105-119.

[9] Açak, M., Düz, S. (2018). Sporun Yaşam Becerilerine Etkisi Ölçeğinin Türk Kültürüne Uyarlanması, İnönü Üniversitesi Eğitim Bilimleri Enstitüsü Dergisi, 5(9), 74-86.

[10] Korkut, F. (2005). Yetişkinlere Yönelik İletişim Becerileri Semineri. Hacettepe Üniversitesi Eğitim Bilimleri Dergisi.28.s.143-149.

[11] Özerkan KN, 2004. Spor Psikolojisine Giriş temel kavramlar. 1. Baskı, Ankara, Nobel Yayın Dağıtım, s. $1-162$.

[12] Açak, M., \& Karademir, T. (2011). Trainer evaluation scale for hearing impaired athletes. World Applied Sciences Journal, 14(5), 716-720. 
[13] Holt, N. L., Tink, L. N., Mandigo, J. L., ve Fox, K. R. (2008). Do youth learn life skills through their involvement in high school sport? A case study. Canadian Journal of Education, 31(2), 281-304.

[14] Fraser-Thomas, J., ve Côté, J. (2009). Understanding adolescents' positive and negative developmental experiences in sport. The Sport Psychologist, 23, 3-23.

[15] Danish, S.J., Forneris, T., Hodge, K., ve Heke, I. (2004). Enhancing youth development through sport. World Leisure, 3, 38-49.

[16] Brunelle, J., Danish, S. J., ve Forneris, T. (2007). The impact of a sport-based life skill program on adolescent prosocial values. Applied Developmental Science, 11(1), 43-55.

[17] Gould, D., Collins, K., Lauer, L., ve Chung, Y. (2007). Coaching life skills through football: a study of award winning high school coaches. Journal of Applied Sport Psychology, 19(1), 16-37.

[18] Gould, D., Flett, R., ve Lauer, L. (2012). The relationship between psychosocial developmental and the sports climate experienced by underserved youth. Psychology of Sport and Exercise, 13(1), 80-87.

[19] Camire, M., Trudel, P., ve Forneris, T. (2009). High school athletes' perspectives on support, communication, negotiation and life skill development. Qualitative Research in Sport and Exercise, 1(1), 72-88. 